\title{
Development of Supplements Prevention System in Oxygen Converter Process in Order to Increase the Economic Efficiency of Steel Melting
}

\author{
Evhen Chuprinov ${ }^{1 *}$, Vitalij Lyalyuk ${ }^{1}$, Hanna Andrushchenko ${ }^{1}$, Daria $\mathrm{Kassim}^{1}$, and Natalia Rad'ko $^{1}$ \\ ${ }^{1}$ State University of Economics and Technology, 50006, Kryvyi Rih, Ukraine
}

\begin{abstract}
The article analyzes the work of the oxygen-converter shop of PJSC «ArcelorMittal Kryvyi Rih». It is shown that almost half of the total number of blowing supplements $(\sim 44 \%)$ is carried out by temperature. In order to improve the conditions of steel smelting and reduce resource costs, calculations were performed and new technological solutions were found in steel smelting to reduce the number of additives. The study of real smelters demonstrated the need for corrective operations in the smelting of steel using scrap metal of different types. Scrap smelts have a clear relationship between the amount of scrap in the charge and the temperature of the melt in the first dump. The addition of «goat» scrap to the charge has a number of uncontrolled effects on the process due to significant fluctuations in the chemical composition of this type of metal charge. An economic analysis with introducing the developed control mechanism over the course of steel smelting into the software system for conditions PSJC «ArcelorMittal Kryvyi Rih» was performed.
\end{abstract}

\section{Introduction}

The modern period of development of the metallurgical industry is characterized by intensification of production, which consists in continuous increase of specific and absolute productivity of metallurgical units, improving the range of manufactured metal products and its quality, which reduces the specific costs of metal, energy and labor costs. As a result, the scale of production of even metal-containing finished products increases in the absence of growth of steelmaking.

Along with the reduction of metal costs, there is a problem associated with production losses. One of the problems is supplements in steel production, which reduce the productivity of the unit and deteriorate the quality of steel. The main cause of blowing supplements is the unstable composition of the metal charge and various fluctuations in the temperature of the loaded charge [1].

The constructive solutions available in real practice to eliminate this problem are not possible for implementation in the conditions of the oxygenconverter shop of ArcelorMittal Kryvyi Rih, which requires a search for new approaches to reduce blowing supplements. In the current conditions, the most optimal direction will be work in the field of software engineering for operational control over the technological process.

The development of information methods of control and management of the technological process has recently opened up new opportunities to improve the processes in metallurgy at all production stages and steel-making production did not stand aside. Researchers obtained mathematical models, discovered new dependencies and refined already known ones [2].

Thus, the purpose of this work is the analysis of melting passports at PJSC "ArcelorMittal Kryvyi Rih" and the search for new technological solutions for steelmaking to reduce the number of additives based on the analysis.

\section{Analysis of previous studies}

A number of studies indicate that the available methods of carbon control do not provide steel of a given chemical composition from the first felling [2, 3]. A significant contribution to solving this problem was made in the works of V.S. Bogushevsky and co-authors [2-4], who developed a series of mathematical models, including static calculation, dynamic prediction and control mechanisms of melting in a closed mode. In [5], an improved method for calculating the material-thermal balance of oxygen-converter steelmaking was developed, which increases the flexibility of the steelmaking process by using the influence of more correct melting conditions. This will improve the technological process and significantly reduce the number of blowing supplements. However, all currently available developments do not allow to finally solve this problem, therefore, the search for additional mechanisms to control the converter process is an urgent problem.

In recent years, advanced methods have been developed to monitor and control processes in metallurgy. The introduction of powerful computing technology allowed technologists to accumulate and analyze large amounts of data in order to introduce

* Corresponding author: itchupa@gmail.com 
advanced automation systems in metallurgy [6], and the development of programming languages allows introducing machine learning elements into metallurgy [7] to refine the developed models directly in the course of technological processes. Due to this, a lot of works have appeared devoted to the introduction into a real production process of models developed to control both the entire technology of steel production, and individual processes. For example, in the literature, there are works on improving the efficiency of using the conversion of $\mathrm{CO}_{2}$ [8], which leads to an improvement in the energy efficiency of the converter process. Much has been done in the development of models for studying processes at the micro level. Thus, in [9], a model was created for macrosegregation of adhesion under the bloom surface, which takes into account the electromagnetic field, flow, heat and transfer of solutes based on the average volume method to study the effect of electromagnetic stirring in the form of M-EMS, and in the study [10], a model was developed dynamic behavior of the molten bath of the MLA-PBF.

Since 2017, the technical department of the PJSC «ArcelorMittal Kryvyi Rig» has begun a large-scale implementation of the software environment «Steelmaking process in the smart-online» mode [11]. The purpose of this project is to ensure the cyclical operation of the steelmaking process and constant correct informing of the manager and technological personnel involved in the process about the state of production online. The system covers all measuring instruments and sensors, starting from the control of the chemical and physical characteristics of the liquid iron leaving the blast furnaces (fig. 1) and scrap (fig. 2), ending with control over the processes in the continuous casting department.

\section{MIXING DEPARTMENT}
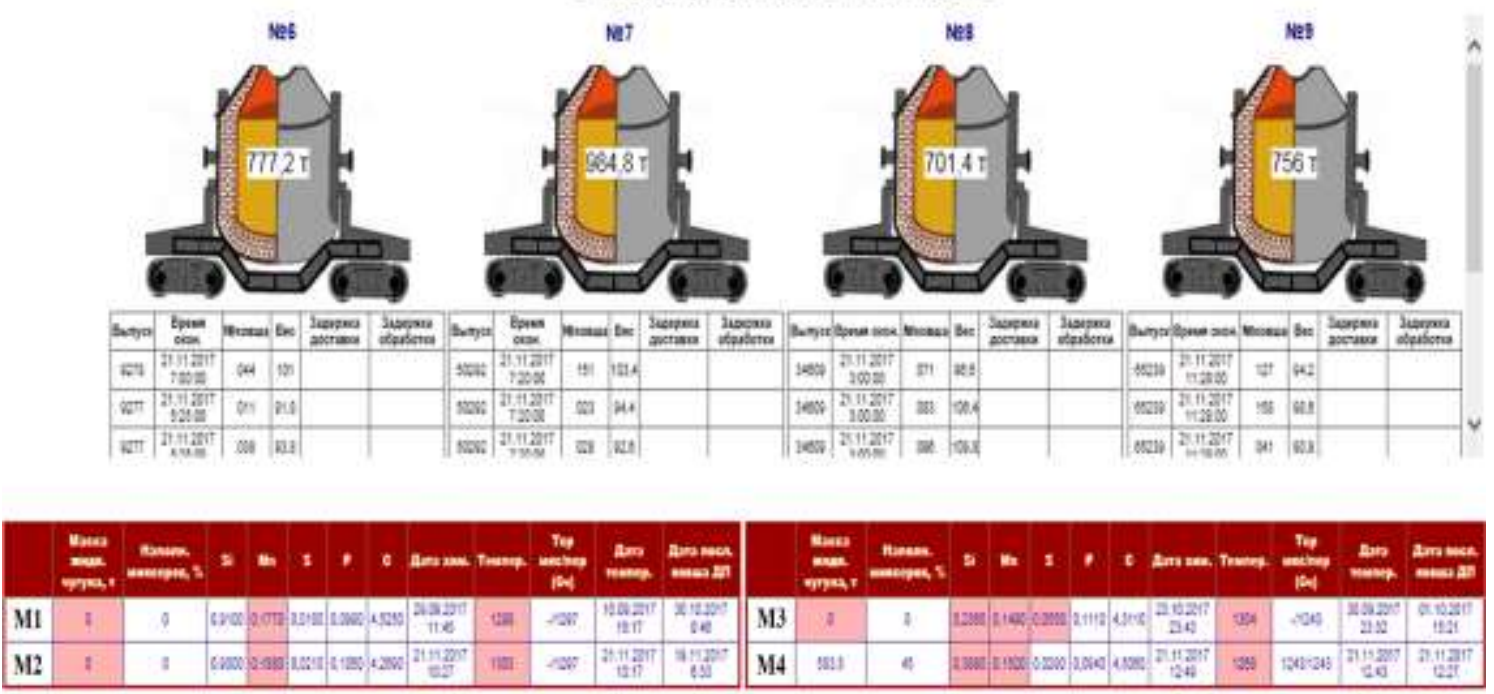

Buckets for pouring into the converter

\begin{tabular}{|c|c|c|c|c|c|c|c|c|c|c|c|c|c|c|}
\hline$\stackrel{\mathbf{m}}{\mathrm{m}}$ & $\sin$ & $\tan$ & $x^{2}$ & Be & $\tan$ & 3 & in & 3 & I & 8 & ovencen & $20 \mathrm{cos}$ & thenches. & $\frac{1}{1}$ \\
\hline$x$ & 15 & 1 & 2 & $2 n$ & 17 & tres & tis & is & 325 & ing & i & & Ac & (x) \\
\hline " & 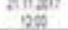 & , & $\omega$ & t: & tee & ans & $t=$ & tant & tow & 8 & : & xes: & & \\
\hline in & $\begin{array}{c}2+1820 \\
\text { nit }\end{array}$ & 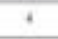 & & int & bet & the & $t x$ & 560 & 63 & 60 & ; & Itwa & Per & $\mathrm{mt}$ \\
\hline$x$ & 3ाये & . & & W2 & 194 & ves & 1120 & : & 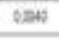 & a & i & Int & & \\
\hline 10 & singer & 4 & & En & 104 & He & $t=1$ & $\tan$ & taxts & 4 & t & sessit & & \\
\hline 111 & $\begin{array}{c}51180 \\
+\infty\end{array}$ & 4 & to & 10 & 124 & $13 x$ & 117 & wee & 6014 & $\cos x$ & t & $3 \sin 4$ & tace & 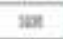 \\
\hline $\mathrm{m}$ & 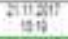 & ' & $m$ & a & 121 & $1 \mathrm{~ms}$ & $12 \%$ & $2 \times \mathrm{EI}$ & txin & tent & $t$ & $=x$ & $p$ & $10 \mathrm{n}$ \\
\hline n & 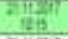 & $:$ & at & को: & int & $14 \mathrm{~s}$ & trix & 205 & +ow & $\mathrm{tan}$ & 1 & & $w$ & 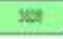 \\
\hline m & 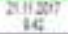 & 2 & sa & sis & 100 & tuse & 172 & $\tan$ & $\mathrm{ces}$ & 6 & $t$ & swas & 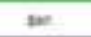 & 384 \\
\hline
\end{tabular}

Cbeacical anahyis samples

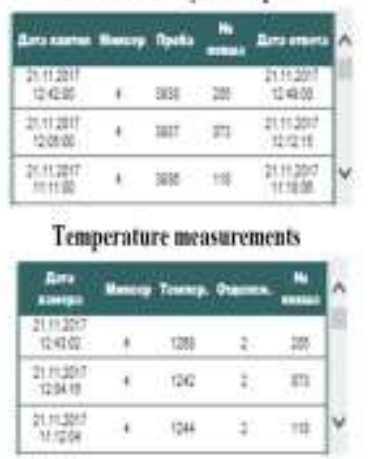

Fig. 1. Characteristics of the liquid iron 


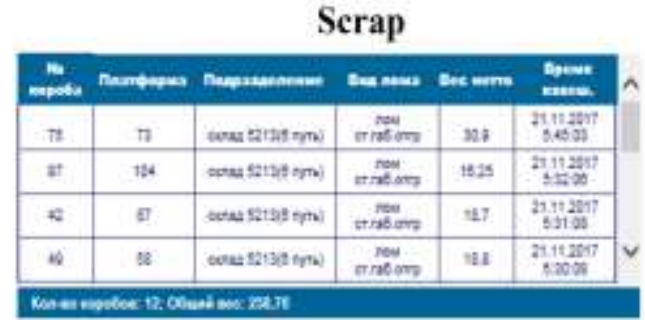

Boxes for filling in converter

Scrap information

\begin{tabular}{|c|c|c|c|c|c|c|c|c|c|c|}
\hline \multicolumn{2}{|c|}{ Armpes: } & \multirow{2}{*}{$\frac{\infty}{s}$} & \multirow{2}{*}{ in } & \multirow{2}{*}{$\begin{array}{c}\text { nee: } \\
\text { ins }\end{array}$} & \multirow{2}{*}{ 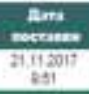 } & \multirow{2}{*}{ 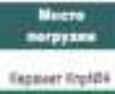 } & \multirow{2}{*}{ 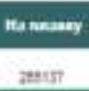 } & \multirow{2}{*}{ 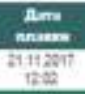 } & \multirow{2}{*}{$\begin{array}{l}\text { Ane } \\
\text { now } \\
350\end{array}$} & \multirow{2}{*}{$\frac{250=1}{2}$} \\
\hline 므 & $=$ & & & & & & & & & \\
\hline 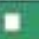 & 70 & in & 24 & an & 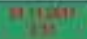 & hosertides: & tanti & 794 & Wi & $\pi$ \\
\hline [ & I & $n$ & $m$ & Mm & 214301 & Wer val ? & & & 61 & 4 \\
\hline$\square$ & $m$ & in & 3 & $72 a$ & 21.15017 & Wert val & $\sin 20$ & $\begin{array}{c}21+1807 \\
1000\end{array}$ & 21 & 4 \\
\hline 므 & $\mathbf{s i}$ & it & 204 & 26203 & 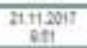 & Gesear 6owhe & 24agt & 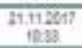 & 4has & 4 \\
\hline 미 & 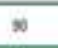 & st & $w$ & serss & 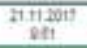 & Couser Koyte. & 205074 & $\begin{array}{c}\text { कinsent? } \\
11.38\end{array}$ & 438 & 4 \\
\hline [] & its & se & ata & 21.4 & श्याइ & Wertat & & & ats & 4 \\
\hline$\square$ & 130 & 94 & as & 3440 & 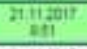 & Went ra ? & & & ast & 8 \\
\hline$\square$ & 24 & it & an & 24150 & $\begin{array}{c}241501 ? \\
45 t\end{array}$ & 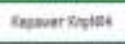 & 2 2ass & 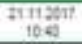 & ex & 8 \\
\hline 口 & H & 4 & 24 & $24 s$ & $\begin{array}{c}21+3501 \\
451\end{array}$ & 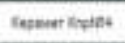 & zana & 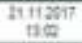 & $4=$ & 2 \\
\hline 미 & 7 & s & $2 \pi$ & 2505 & $\begin{array}{c}21.15017 \\
061\end{array}$ & Totaur Twiat & anse & 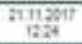 & 45 & 7 \\
\hline ㅁ & as & 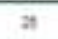 & $m$ & $27 m$ & $\begin{array}{l}2412017 \\
601\end{array}$ & Wen mat & ล⿻ & $29128 \pi$ & as & 8 \\
\hline
\end{tabular}

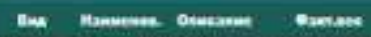

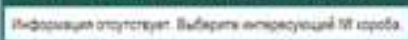

Fig. 2. Characteristics of the scrap

\section{Materials, methods and results of the study}

The use and implementation of this system made it possible to carry out a complete analysis of a number of technological processes, identify the relationship between various factors and identify problem areas in the adopted technology. The most important role for identifying problem points in the steel smelting process is played by the smelting passport and batching model (fig. 3), allowing to control all influences on the molten metal. As part of this work, the authors analyzed an array of more than 500 melting's passports.

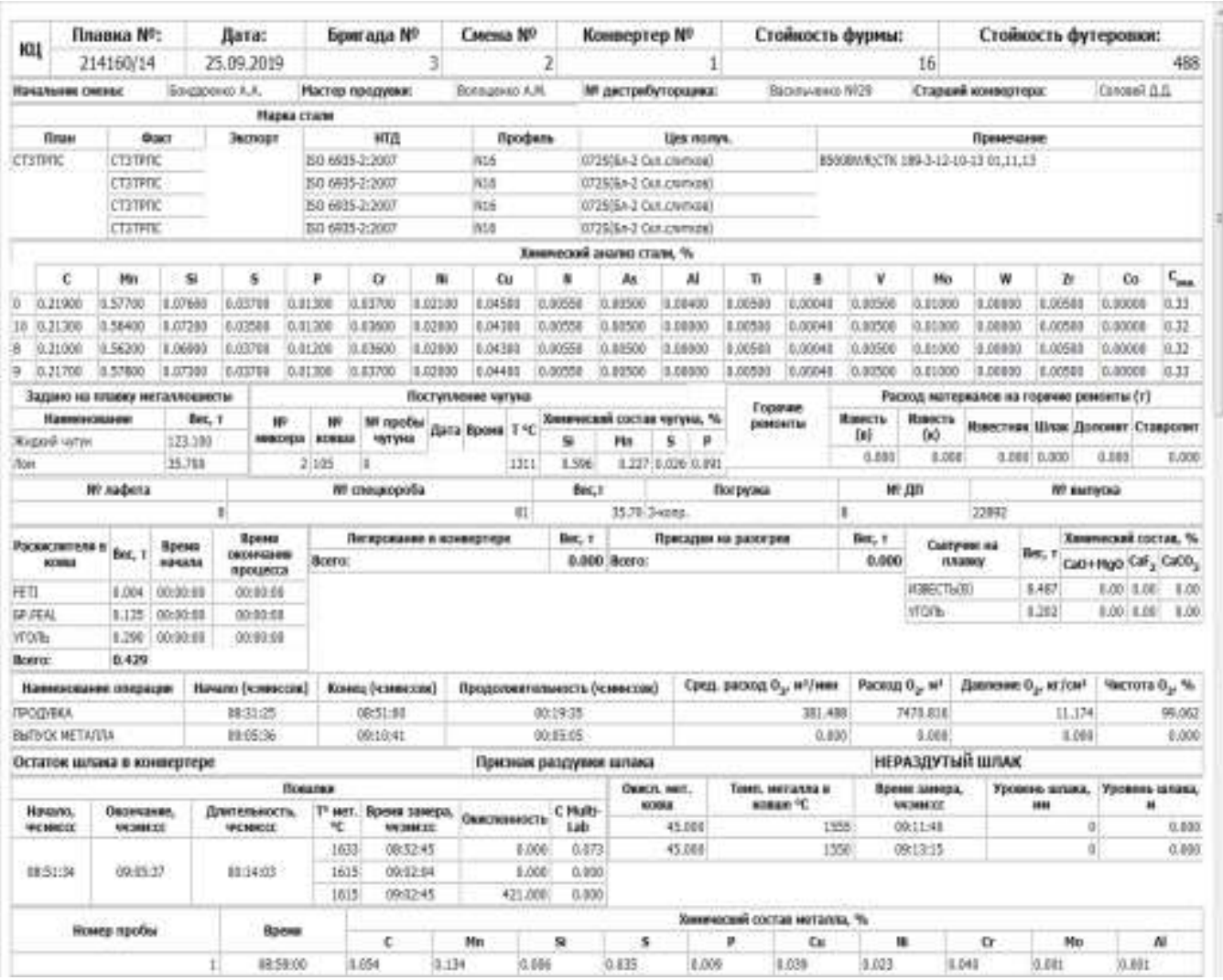




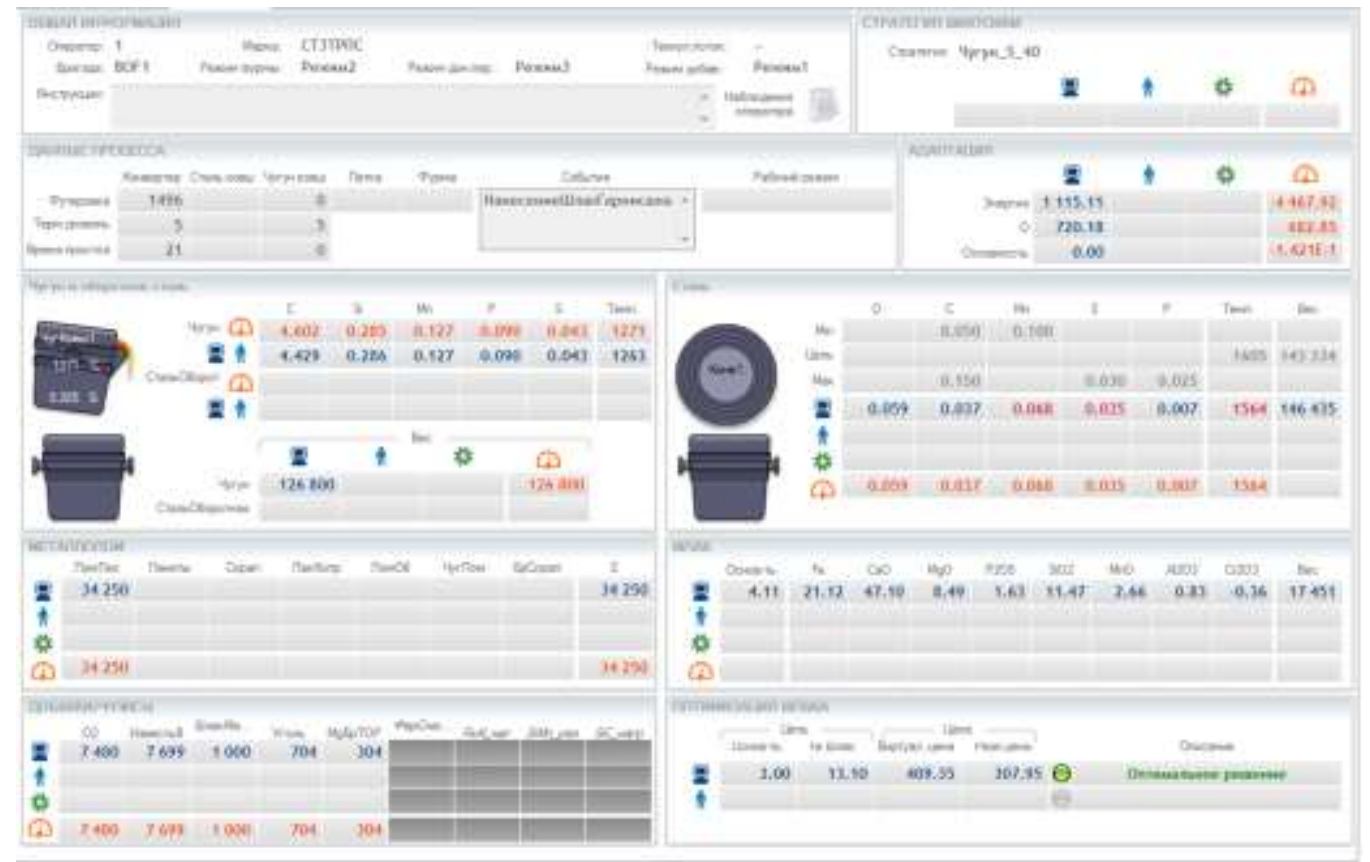

Fig. 3. Passport of the melting and batching model

According to the analysis of the oxygen-converter shop of PJSC «ArcelorMittal Kryvyi Rih» almost half of the total number of blowing supplements $(\sim 44 \%)$ is carried out by temperature. The physical heat of liquid cast iron contributes to the converter bath about $50-54 \%$ of the total heat, and an increase in the temperature of the cast iron, respectively, leads to an increase in the temperature of the bath.

Analyzing of the melting's passports, new relationships were obtained between the indicators of the oxygen-converter process, which are typical for the conditions of the steelmaking shop of PJSC «ArcelorMittal Kriviy Rih».

The dependence of the metal temperature on the first pile on the temperature of cast iron (fig. 4) is represented by the equation:

$$
T_{M}=-0.0002 \cdot T_{c . i .}^{2}+0.5444 \cdot T_{c . i .}+1142.6, r^{2}=0.45,
$$

where $T_{M}$ is the temperature of the metal on the first dump, ${ }^{\circ} \mathrm{C} ; \mathrm{T}_{\text {c.i. }}-$ temperature of cast iron, which is poured into the converter, ${ }^{\circ} \mathrm{C}$.

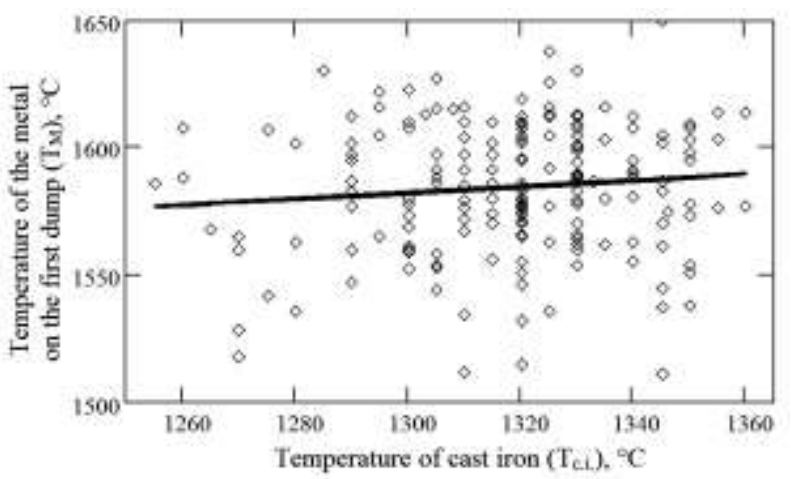

Fig. 4. The dependence of the temperature of the metal on the first dump on the temperature of cast iron

The influence of the amount of cast iron on the temperature of the metal on the first dump (fig. 5) is expressed by the equation:

$$
T_{M}=0.0109 \cdot Q^{2}-0.4442 \cdot Q+1556.3, r^{2}=0.51,
$$

where $\mathrm{Q}$ is the amount of cast iron, $\%$.

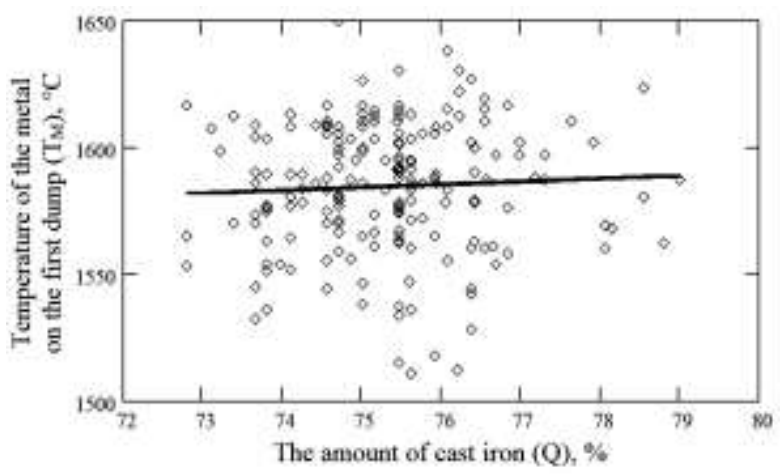

Fig. 5. The dependence of the temperature of the metal on the first dump on the amount of cast iron

The dependence of the metal temperature on the Mn content in the cast iron was also revealed - with the increase of the manganese content in the cast iron the metal temperature decreases (fig. 6):

$$
\begin{gathered}
T_{M}=7.1733 \cdot[\mathrm{Mn}]^{2}{ }_{c . i .}-44.9 \cdot[\mathrm{Mn}]_{c . i .}+1603.8, \\
r^{2}=0.47,
\end{gathered}
$$

where $[\mathrm{Mn}]_{\text {c.i. }}-$ manganese content in cast iron, $\%$. 


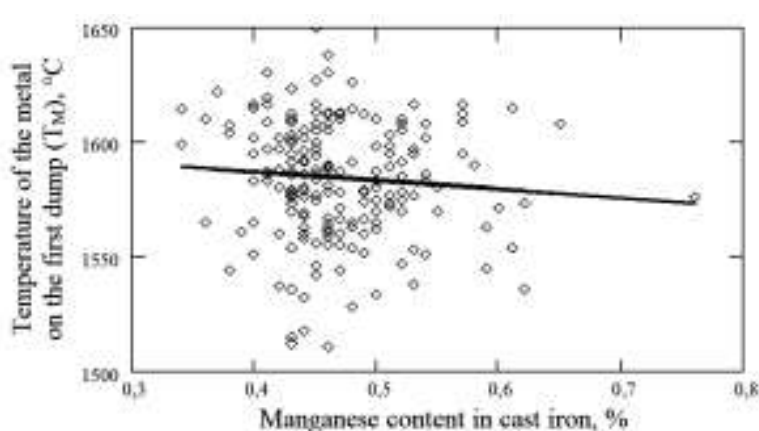

Fig. 6. Dependence of metal temperature on the first dump on the Mn content in cast iron

As the amount of scrap in the filling decreases, the temperature of the metal on the first dump increases (fig. 7). This is due to the fact that the scrap is a coolant, for its dissolution consumes a certain amount of heat. This dependence is expressed by the equation:

$$
T_{M}=-0.0559 \cdot P^{2}+1.3936 \cdot P+1584.2, r^{2}=0.56,
$$

where $\mathrm{P}$ is the content of scrap in the metal charge, $\%$.

Scrap enters to the landfill with a certain degree of slagging, its cooling capacity is greater than that of pure scrap.

All this contributes to the fact that with increasing amount of slag scrap in the filling there is a decrease in metal temperature (fig. 8). This dependence is expressed by the equation:

$$
T_{M}=0.006 \cdot P_{s}^{2}-1.2823 \cdot P_{s}+1589.6, r^{2}=0.41,
$$

where $\mathrm{P}_{\mathrm{c}}$ is the content of slag scrap in the metal, $\%$.

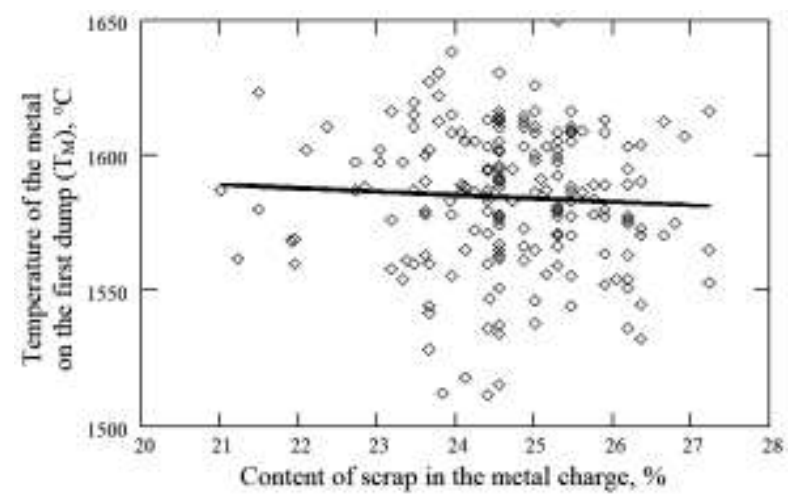

Fig. 7. The dependence of the temperature of the metal on the first dump on the amount of scrap in the charge

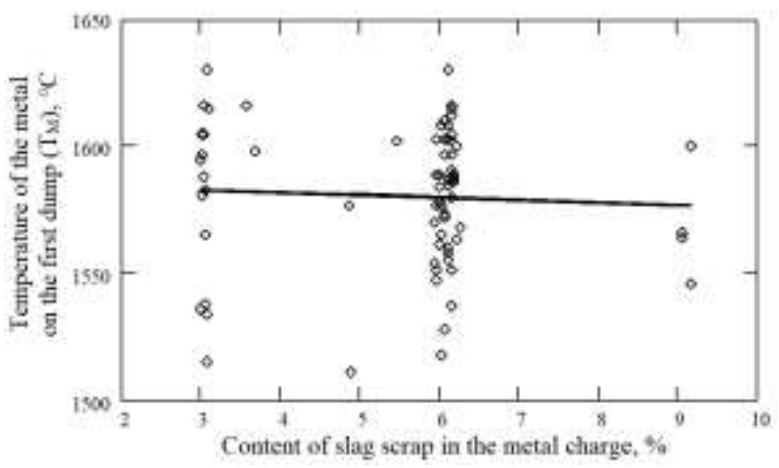

Fig. 8. The dependence of the temperature of the metal on the first dump on the amount of slag scrap in the charge

The impact of the so-called "goat" scrap has a slightly different character. With an increase in the amount of "goat" scrap loaded, there is an increase in metal temperature (fig. 9).

All these dependences confirm the fact that the "goat" scrap does not actually perform its function as a coolant and leads to an increase in the number of blowing supplements. When sampling unmelted scrap increases heat dissipation due to the cooling effect is $1400-1500 \mathrm{~kJ} / \mathrm{kg}$, which is equal to the same value of scrap metal. As a result, technologists are forced to perform blowing supplements operations on temperature with overheating of the melt [12].

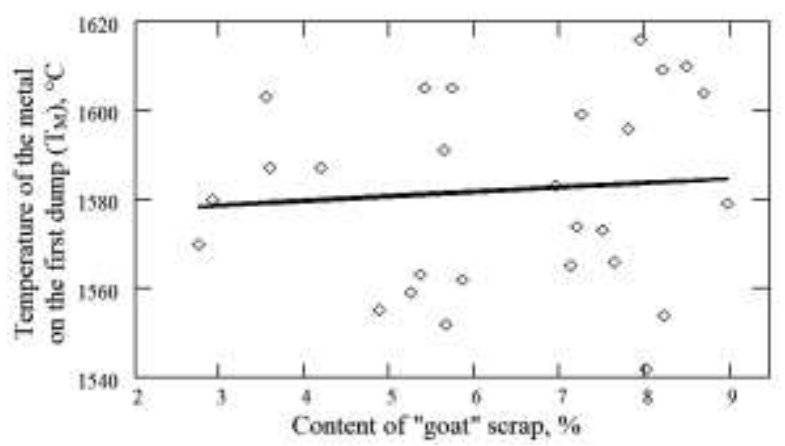

Fig. 9. The dependence of the temperature of the metal on the first dump on the amount of «goat» scrap in the charge

The expression of this dependence is shown by the following equation:

$$
T_{M}=-0.0371 \cdot P_{g}^{2}-0.619 \cdot P_{g}+1574.9, r^{2}=0.43,
$$

where $\mathrm{P}_{\mathrm{g}}$ is the content of «goat» scrap in the metal charge, $\%$.

The use of the obtained mathematical models and their introduction into the smart matrix of the oxygenconverter process (fig. 10) made it possible to significantly improve the efficiency of the shop and improve the technology of steelmaking. 


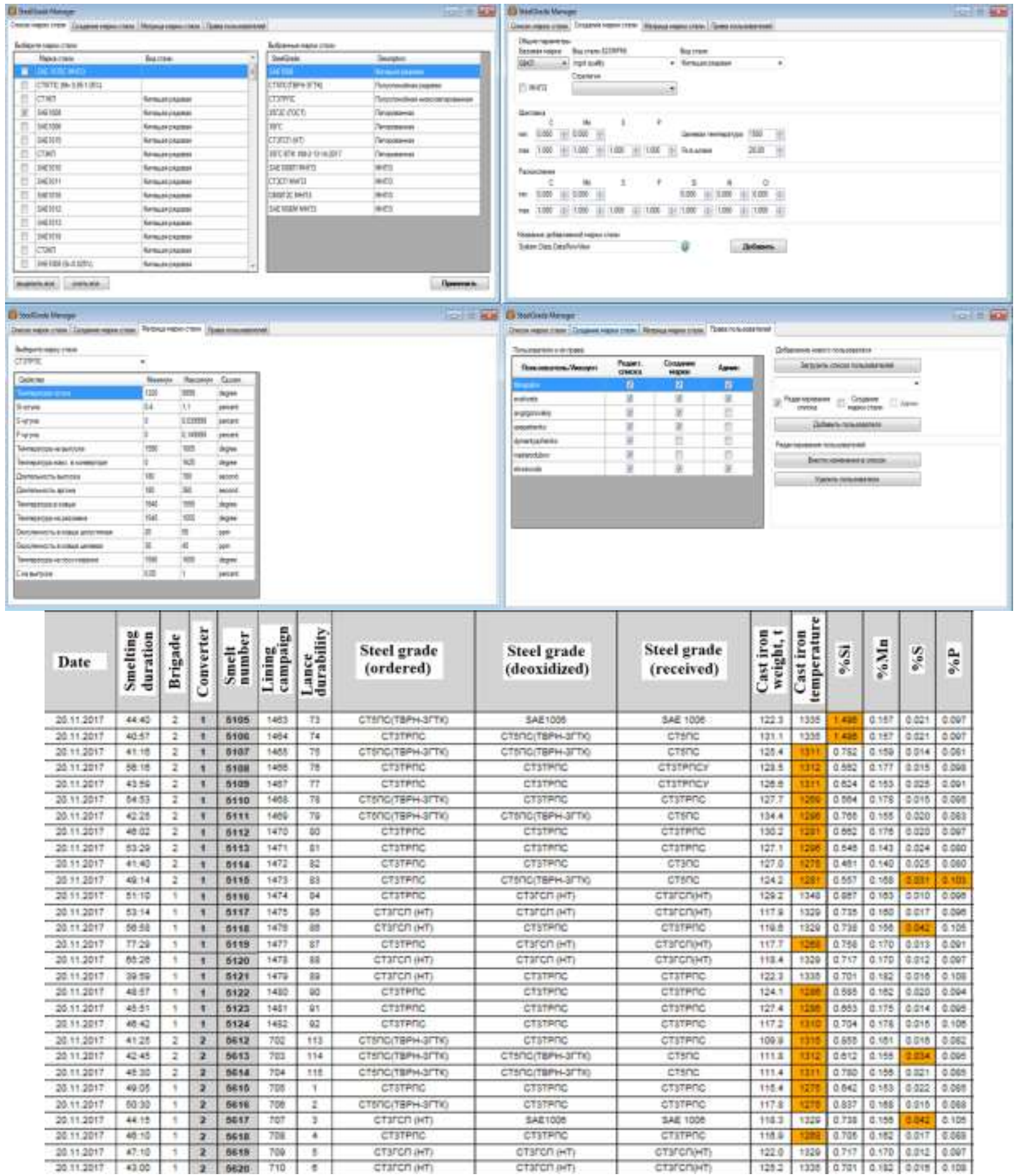

Fig. 10. Smart matrix of the oxygen-converter process

The corrective operations proposed by the authors of the article are based on calculations performed using the material-thermal balance of the oxygen-converter process.

The amount of heat required on average for converter melting is $285 \cdot 10^{3} \mathrm{MJ}$. Of these, the largest amount of heat $(50-54 \%)$ gives the physical heat of cast iron, coming from the blast furnace shop. The share of chemical heat accounts for $34-35 \%$ of heat input (in the processing of pig iron, the amount of additional heat increases slightly). Blast furnace slag, which enters the converter from the mixer, contributes about $0.6 \%$ of heat [13].
Thus, in the processing of pig iron weighing 10 tons, the same chemical composition as pig iron, is additionally made:

$$
\begin{aligned}
{[\mathrm{C}]=} & 1,10-0,20=0,90 \%=378 \mathrm{~kg}[\mathrm{C}] \\
{[\mathrm{Si}]=} & 0,23-0,08=0,15 \%=63 \mathrm{~kg}[\mathrm{Si}] \\
{[\mathrm{Mn}]=} & 0,46-0,46=0,00 \%=0 \mathrm{~kg}[\mathrm{Mn}] \\
{[\mathrm{P}]=} & 0,06-0,04=0,02 \%=8,4 \mathrm{~kg}[\mathrm{P}]
\end{aligned}
$$

which gives due to chemical reactions the arrival of heat in the amount $17773 \mathrm{~kJ}$.

That is, for 1 ton of pig iron enters the bath of the converter an additional $17773 \mathrm{~kJ}$. The cooling effect of cast iron is slightly greater than in comparison with 
ordinary scrap metal, which is associated with a smaller particle size distribution and, accordingly, a larger area of interaction (table 1).

Table. 1. The amount of heat given off by the metal additive

\begin{tabular}{|c|c|c|}
\hline Name & Scrap (1 t) & Pig iron (1 t) \\
\hline Heat capacity & $714 \mathrm{~kJ}$ & $2256 \mathrm{~kJ}$ \\
\hline Cooling effect & $-1.45 \mathrm{MJ}$ & $-1.8 \mathrm{MJ}$ \\
\hline Total & $-0.736 \mathrm{MJ}$ & $0.456 \mathrm{MJ}$ \\
\hline
\end{tabular}

As can be seen from table. 1, the difference in heat input is $1,192 \mathrm{MJ}$ per 1 ton of pig iron. The most effective compensator for excess heat in terms of economic feasibility is limestone $\left(\mathrm{CaCO}_{3}\right)$, the cooling effect of which is $12 \cdot 10^{3} \mathrm{~kJ}$ per 1 ton of cast iron. The main disadvantage of limestone - low reactivity, which does not allow the optimal amount to react in the necessary time interval to ensure high productivity of the steelmaking unit. As a result, the technologist is forced to increase the amount of limestone consumption by 30 $40 \%$, which in total is $130-140 \mathrm{~kg}$ of $\mathrm{CaCO}_{3}$ per 1 ton of pig iron.

Along with pig iron, steel scrap is used, the degree of contamination of which ranges from 5 to $40 \%$, which negatively affects the arrival of heat. The heat capacity of scrap is $714 \mathrm{~kJ} / \mathrm{t}$. And from the heat of formation and the content of chemicals in the slag, from the steel scrap can calculate its heat capacity [13]:

$$
\begin{aligned}
\mathrm{FeO} & =23.32 \mathrm{~kJ} \\
\mathrm{Fe}_{2} \mathrm{O}_{3} & =23.86 \mathrm{~kJ} \\
\mathrm{CaO} & =168.72 \mathrm{~kJ} \\
\mathrm{SiO}_{2} & =108.51 \mathrm{~kJ} \\
\mathrm{MgO} & =49.97 \mathrm{~kJ} \\
\mathrm{Al}_{2} \mathrm{O}_{3} & =88.83 \mathrm{~kJ} \\
\mathrm{MnO} & =40.08 \mathrm{~kJ} \\
\mathrm{~S} & =0.133 \mathrm{~kJ} \\
\text { Total: } & =503 \mathrm{~kJ}
\end{aligned}
$$

Analysis of the difference between the heat capacities of scrap and steel scrap $(714 \mathrm{~kJ} / \mathrm{t}$ and $503 \mathrm{~kJ} / \mathrm{t}$, respectively) gives an answer to the questions of technologists of PJSC «ArcelorMittal Kryvyi Rih» relatively large number of «cold» melting trunks that come with steel scrap. Given that the amount of steel scrap averages 10 tons per smelting, it becomes possible to calculate the amount of heat lost due to low heat capacity and a huge cooling effect. Thus, in scrap it varies between $1400-1500 \mathrm{~kJ} / \mathrm{t}$, and in steel scrap $1600-1800 \mathrm{~kJ} / \mathrm{t}$. The amount of slag in the steel scrap is $20 \%$, and the heat input from 1 ton is $671.8 \mathrm{~kJ}$ [13]. The heat capacity of steel scrap is less than in scrap by 42.2 $\mathrm{kJ} / \mathrm{t}$. Along with this, there is a sharp increase in the cooling effect of scrap (table 2).

Table. 2. Cooling effect of scrap and steel scrap

\begin{tabular}{|c|c|c|}
\hline Name & Scrap (1 t) & Steel scrap (1 t) \\
\hline Heat capacity & $714 \mathrm{~kJ}$ & $671.8 \mathrm{~kJ}$ \\
\hline Cooling effect & $-1.45 \mathrm{MJ}$ & $-1.7 \mathrm{MJ}$ \\
\hline Total & $-0.736 \mathrm{MJ}$ & $-1.028 \mathrm{MJ}$ \\
\hline
\end{tabular}

As can be seen from table. 2, the difference between scrap and steel scrap is 0.292 MJ per 1 ton of scrap metal, which requires additional technological operations for its leveling. The most appropriate in this case is to add ground coke to the purge. Calculations performed according to the existing models of material-heat balance of steel smelting in an oxygen converter [14, 15] show that $104.65 \mathrm{~kg}$ of carbon or $120 \mathrm{~kg}$ of coke per ton of scrap are needed to generate this amount of heat.

A study of meltings passports shows that the share of "goat" scrap is $8 \%$ of all meltings. In the analysis of these meltings passports the tendency is noticed that at increase in quantity of «goat» scrap the temperature on the first dump increases, which is mainly due to incomplete penetration of scrap. This is confirmed by the data on the average yield of the metal. Thus, in conventional batching the yield of metal is 146.9 tons, and in the processing of «goat» scrap - 141.6 tons.

In the process of dissolving the steel scrap is heat absorption with the same as in scrap, heat dissipation in the range of $1400-1500 \mathrm{~kJ} / \mathrm{kg}$, and its heat capacity is lower than that of scrap metal. Therefore, to avoid blowing supplements by temperature, it is necessary to overheat the bath of the converter by $20-30{ }^{\circ} \mathrm{C}$, which affects on the oxidation of the metal and the amount of dissolved nitrogen in the metal.

\section{Results, discussion and economic justification}

The performed analysis of the oxygen-converter smelts showed that the average duration of one smelting on AMKR is 54 minutes, and the blowing supplements with duration of 4-5 minutes is carried out on each melt (fig. 11).

Experimental smelting operations carried out in the converter shop of PJSC «ArcelorMittal Kriviy Rig» with using mathematical models developed by the authors, showed the possibility of obtaining the specified physical and chemical properties of the metal at the outlet in $75-85 \%$ of all cases.

An analysis of the shop's operation shows that one converter smelts 3724 tons of steel per day, with the duration of technological operations spent on one melt 54 minutes. If the developed and proposed adjustments are made, the duration of one melt will be reduced to 50 minutes, and the converter productivity will increase to 4032 tons of steel per day. Thus, the daily increase in the volume of steel will be 308 tons. Since not all smelting can be carried out without blowing supplements, and taking their quantity as $50 \%$, additional steel volume from one converter will be 154 tons. With the average price of 1 ton of steel at $\$ 225$, the cost of additional production will amount to $\$ 38.500$ per converter. 


\begin{tabular}{|c|c|}
\hline \multicolumn{2}{|c|}{ K5 } \\
\hline Loose to melt & Ferroalloys \\
\hline \begin{tabular}{c|c|} 
Dolomite & 925 \\
Coal & 0 \\
\end{tabular} & \begin{tabular}{ll|l|} 
FelMn78 18671 \\
\end{tabular} \\
\hline $\begin{array}{ll}\text { Cotil } & 0 \\
\text { Dolomite } & 0\end{array}$ & \begin{tabular}{|l|l|} 
SaMn 21700 \\
\end{tabular} \\
\hline \begin{tabular}{l|l} 
Lime & 0 \\
\end{tabular} & \begin{tabular}{|l|l|} 
FeSCO5 & 5775 \\
\end{tabular} \\
\hline Lime 0 & \begin{tabular}{|l|l|} 
FeMnB8 & 1290 \\
\end{tabular} \\
\hline MgO briquette 0 & \\
\hline Melt number & 255395 \\
\hline Steel grade & St 3 he CCM \\
\hline Start time & 122.24 \\
\hline End time (forecast) & 13.07 \\
\hline Bucket no, Weight & 073Ne4: $122 \pi, 1242^{*} \mathrm{C}$ \\
\hline Box No. & Na9: 35.95 \\
\hline Oxygen consumption & 3445.87 \\
\hline Lining durability & 210 \\
\hline Lance durability & 100 \\
\hline Stage & End of smelting \\
\hline Stage duration & $00: 11: 20$ \\
\hline Events & $\begin{array}{l}\text { Blowing, Slag } \\
\text { pumping, Skewer }\end{array}$ \\
\hline Reason for downtime & \\
\hline
\end{tabular}

Fig. 11. Converter control screen

\section{Conclusions}

The use of modern software solutions for the automation of industrial processes is gradually becoming the most important attribute of large metallurgical enterprises. The results presented in the work clearly demonstrate that traditional steelmaking technologies have huge reserves for improvement.

The use of mathematical models, developed and implemented by the authors in production processes in PJSC «ArcelorMittal Kryvyi Rih» conditions, made it possible to obtain an additional yield of suitable metal worth $\$ 38.500$ on a daily basis.

Comparing the results of the analysis of smelting passports and the obtained mathematical models through the prism of the possibility of introducing them into a real production process with the results of foreign studies [6-10], we can say that the proposals developed in the article are at a high technological level.

The value of the accuracy of the approximation of the developed computational models shows their sufficient accuracy for use in the modern oxygen-converter process. Despite the fact that the obtained equations, although they reflect the trends known to technologists, their introduction into the converter process control system through the use of modern computer technologies will allow improving and improving these models "underway", thereby increasing the efficiency of the shop with each melting.

Given the constant growth of the meltings pool passport database, the next stage of this work will be the development and implementation of a «smart» control system for the oxygen-converter process, which could take into account the accumulated «experience» to select the most optimal course of steelmaking.

\section{References}

1. S.V. Kolpakov, R.V. Starov, V.V. Smoktij and others, "Steel production technology in modern converter shops", M: Mashinostroenie, 1991, 463 p.

2. V.S. Bogushevskij, S.G. Melnik and S.V. Zhuk, "Steel decarburization as the main parameter of optimal control of oxygen-converter smelting", Metall i lityo Ukrainy, 2014, 2, S. 14-16.

3. V.S. Bogushevskij and K.V. Yegorov, "Control of bath dynamics during purge as a component of converter melting control system", Naukovi visti NTUU «KPI», 2013, № 1, S. 51-56.

4. V.S. Bogushevskij, G.G. Grabovskij, V.M. Mihajlov and others, "Computer model for calculating the charge and purge converter smelting", Stal, 2006, 1, S. 18-21.

5. A.V. Sushenko, E.S. Popov, R.S. Sidorchuk and others, "Improving the methodology and developing an application program for calculating the oxygen balance of the cast melting", Visnik Priazovskogo derzhavnogo tehnichnogo universitetu, 2013, Seriya: Tehnichni nauki, 26, pp. 46-56.

6. Qi, Cc. Big data management in the mining industry. Int J Miner Metall Mater27, 131-139 (2020). https://doi.org/10.1007/s12613-019-1937-z

7. Holm, E.A., Cohn, R., Gao, N. et al. Overview: Computer Vision and Machine Learning for Microstructural Characterization and Analysis. Metall Mater Trans A 51, 5985-5999 (2020). https://doi.org/10.1007/s11661-020-06008-4

8. Zhu, R., Han, Bc., Dong, K. et al. A review of carbon dioxide disposal technology in the converter steelmaking process. Int J Miner Metall Mater 27, 1421-1429 (2020). https://doi.org/10.1007/s12613-020-2065-5

9. Huo, Yk., Zhao, Lh., An, Hh. et al. Model prediction of the effect of in-mold electromagnetic stirring on negative segregation under bloom surface. Int $\mathbf{J}$ Miner Metall Mater 27, 319-327 (2020). https://doi.org/10.1007/s12613-019-1906-6

10. Cao, L. Numerical Investigation on Molten Pool Dynamics During Multi-laser Array Powder Bed Fusion Process. Metall Mater Trans A 52, 211-227 (2021). https://doi.org/10.1007/s11661-020-06076-6

11. Technical department of the PJSC «ArcelorMittal Kryvyi Rig», «Steelmaking process in the smartonline» mode, VII Conference of the Steelmakers, 23-24 November, 2017, 15 p.

12. V.I. Baptizmanskij, B.M. Bojchenko, O.G. Velichko and others, "Steelmaking: Manual", K.: IZMN, 1996, $400 \mathrm{~s}$.

13. T.G. Saberzyanov, "Subregular version of the general mathematical model of thermodynamics of metallurgical slag", Izvestiya vysshih uchebnyh zavedenij. Chernaya metallurgiya, 2001, 12, pp. 5355.

14. A.V. Sushenko and I.A. Fejerejzen, "Comparative analysis of methods for calculating the material and thermal balances of oxygen-converter smelting", 
Visnik Priazovskogo derzhavnogo tehnichnogo universitetu, 2013, 27, pp. 17-28.

15. V.N. Shinkin, "Mathematical model of technological parameters' calculation of flanging press and the formation criterion of corrugation defect of steel sheet's edge", CIS Iron and Steel Review, 2017, Vol. 13, pp. 44-47. 